\title{
Plant Species Diversity and Structure in Homegarden Agroforestry Systems of Bulen District, North-Western Ethiopia
}

\author{
Megabit Beyene', Muktar Mohammed ${ }^{2 *}$ and Lisanework Nigatu ${ }^{1}$ \\ ${ }^{1}$ College of Agriculture and Environmental Sciences, Haramaya University, Ethiopia \\ ${ }^{2}$ College of Natural Resource and Environmental Sciences, Oda-Bultum University, Ethiopia
}

Submission: November 08, 2018; Published: December 03, 2018

*Corresponding author: Muktar Mohammed, College of Natural Resource and Environmental Sciences, Oda-Bultum University, Ethiopia

\begin{abstract}
Homegarden agroforestry system mostly constitutes complex multi-strata than other agroforestry systems. The aim of this study was to investigate the structure, composition and diversity of plant species growing in homegarden agroforestry system in Bulen district, North-West Ethiopia. The study was conducted in five kebeles of the district, which were randomly selected. Systematic random sampling procedure was employed to select households from each kebele. Thus, 138 households from each site were selected proportionally. The result from the surveyed 138 households indicated that $110(80 \%)$ were practicing homegarden agroforestry system. The determination of vertical and horizontal structure of the vegetation was conducted for 110 home gardens. All woody species and herbaceous species were counted and recorded in $5 \mathrm{~m}$ x $5 \mathrm{~m}$ and $1 \mathrm{~m}$ x $1 \mathrm{~m}$ quadrants, respectively. Furthermore, a total of 22 plant species belonging to 15 families were recorded in sampled home gardens in which about 3-5 different species of plants per quadrant were recorded. A higher Shannon diversity index of plant species in the study area were $\left(H^{\prime}=2.44\right)$ while the lower Shannon diversity index were $\left(H^{\prime}=2.21\right)$. The homegarden agroforestry system had complex structure both vertically and horizontally, which in turn provide economic benefit and ecological service to the households.
\end{abstract}

Keywords: Homegarden Agroforestry System; Vegetation Composition; Woody Plant; Herbaceous Plant; Diversity Index

\section{Introduction}

Land around the farmers house with trees are one of agroforestry practices known to be ecologically sustainable and diversifies livelihood of local community. Homegarden agroforestry system is the land use system involving deliberate management of multipurpose trees and shrubs in intimate association with annual and perennial agricultural crops and invariably livestock within the compounds of individual houses, being intensively managed by family labour [1]. Well-designed structure of homegarden agroforestry can give the desired benefit through efficient resource utilization. Homegardens are fundamentally different from large scale agricultural systems, mainly because they are small in size, intensively managed production systems and require low levels of agricultural inputs the structure of home garden in the tropics is based on horizontal and vertical strata. Horizontal structure is determined by localization of each homegarden species with in the garden using farmer's house as a reference. Vertical structure reflects degree of species specialization and complexity [2]. In order to maintain agro-ecosystem resilience and to meet the homegarden products for requirements of the people during stress of climatic hazard like drought, flood, scientific information is required.
Homegarden agroforestry systems in the tropics are known for their structural complexity and diversity in crop and other plant species [1]. The cultivation of different crops in home gardens is regarded as a strategy of farmers to diversify their subsistence and cash needs. Diversification also helps to stabilize yield and income in cases of incidences of disease and pests, and market price fluctuations. Although the positive impacts of crop diversity on homegarden sustainability have been widely discussed [3], the precise relation between diversity and sustainability is still in open debate [4]. A basic question is how diversity in home gardens can best be characterized. Normally, diversity is expressed as the average number of species per homegarden in a specific region. Currently, increasing attention is given to the diverse nature of species diversity and their variation in time and space. For instance, ecologists differentiate between alpha (the diversity in a particular area or ecosystem), beta (the change of species diversity between ecosystems) and gamma (the overall species diversity for the different ecosystems within a region) $[5,6]$.

Species composition, structure and function of home gardens may be influenced by ecological, socio-economic and cultural factors, such as distance from urban markets, household size and 
composition, environmental degradation and family tradition $[7,8]$, home gardens, whether found in rural or urban areas, are characterized by a structural complexity and multi functionality, which enables the provision of different benefits to ecosystems and people. Lack of scientific knowledge on homegarden agroforestry systems structure and species diversity may pave the way for destruction of diverse plant species and results in the loss of homegarden structure. There is no documented study made on homegarden agroforestry systems structure, composition and diversity of plant species in study area. It is imperative to undertake investigation in to various aspect of biodiversity in homegarden agroforestry system of the area and their subsequent contribution to the household livelihood. Thus, the study was designed with the aim to investigate the structure, composition and diversity of plant species in homegardens agroforestry systems of the study area.

\section{Material and methods}

\section{Description of the Study Area}

The study was conducted in Bulen district, North-western Ethiopia. Geographically, the district is located at $10036^{\prime} 10.6^{\prime \prime}$ northern latitude and $36004^{\prime} 57^{\prime \prime}$ eastern longitude. Bulen is one of the 20 woredas in the Benishangul-Gumuz Regional state of Ethiopia. It is located at $634 \mathrm{~km}$ from the capital of Ethiopia, Addis Ababa in western part of the country and $585 \mathrm{~km}$ from Assossa the capital of the Region in the Northern direction. Bulen woreda has a total area of 325233.75 ha and for administrative purpose; it is structured into 17 rural and 2 urban Kebeles. Topographically the district lies within an elevation range of $500-1695$ meters above sea level. The woreda has three agroecological Zones, Dega (5\%), Weynadega (20\%) \& Kolla (75\%). The annual temperature of the Woreda ranges from $28^{\circ} \mathrm{C}-34^{\circ} \mathrm{C}$ and the annual rainfall ranges $1200-1500 \mathrm{~mm}$. With regard to land use, the largest area, 144,583.25ha (44.45\%), is cultivable land, 36,370 ha $(11.2 \%)$ of the woreda is intensively cultivated for annual crops, 40,462 ha $(12.44 \%)$ is a grazing land, 69,344 ha $(21.32 \%)$ is forest land and 34,475 ha $(10.6 \%)$ is covered by others.

\section{Research Method and Design}

The research methodology employed for this study was exploratory research methods. This method is preferred because there is no evidence that shows about structure of plant species diversity in homegarden and its economic contribution to household. From among exploratory research methods, descriptive and economic survey was used to identify plant species diversity and its economic contribution to household.

\section{Sample Size and Sampling Procedure}

The study was conducted in five randomly selected kebeles of the district, namely: Baruda, Bulen 01, Dobina Enkonti, Baphirina Mata, and Morana Ekosaki. Then, systematic random sampling used to select households from each kebeles. There were 747, 746, 922, 519 and 319 of total household members in each kebeles, respectively. To determine sample distribution and the corresponding target population in the study area. $\mathrm{N}=\left(\mathrm{z}^{\wedge} 2\right.$ $(1-p) p) / \mathrm{e}^{\wedge} 2=\left(\left[1.96 \rrbracket^{\wedge} 2(1-0.9) 0.9\right) /\left[0.05 \rrbracket^{\wedge} 2=138\right.\right.$, where; $z=$ the $\mathrm{z}$-value the desired degree of confidence, $\mathrm{p}=$ an estimate of the population proportion, and $\mathrm{e}=$ the absolute size of the error in estimating $\mathrm{p}$ that the research is willing to permit (Table 1).

Table 1: Sample distribution and the corresponding target population.

\begin{tabular}{|c|c|c|c|}
\hline $\begin{array}{c}\text { Name of } \\
\text { kebeles }\end{array}$ & $\begin{array}{c}\text { Total No.of } \\
\text { households }\end{array}$ & Percentage (\%) & $\begin{array}{c}\text { Sample size of } \\
\text { households }\end{array}$ \\
\hline Baruda & 747 & 23 & 32 \\
\hline Dobina Enkonti & 922 & 28 & 39 \\
\hline Baphirina mata & 519 & 16 & 22 \\
\hline $\begin{array}{c}\text { Morana } \\
\text { Ekosaki }\end{array}$ & 319 & 10 & 13 \\
\hline Bulen 01 & 746 & 23 & 32 \\
\hline & 3253 & 100 & 138 \\
\hline
\end{tabular}

Table 2: The number of homegarden found in different size category.

\begin{tabular}{|c|c|c|c|}
\hline HG category & Range of category & No.of HG & Percent (\%) \\
\hline Small & $0.031-0.25 \mathrm{ha}$ & 41 & 38 \\
\hline Medium & $0.25-0.5 \mathrm{ha}$ & 58 & 54 \\
\hline Large & $0.5-0.75 \mathrm{ha}$ & 11 & 8 \\
\hline Total & & 110 & 100 \\
\hline
\end{tabular}

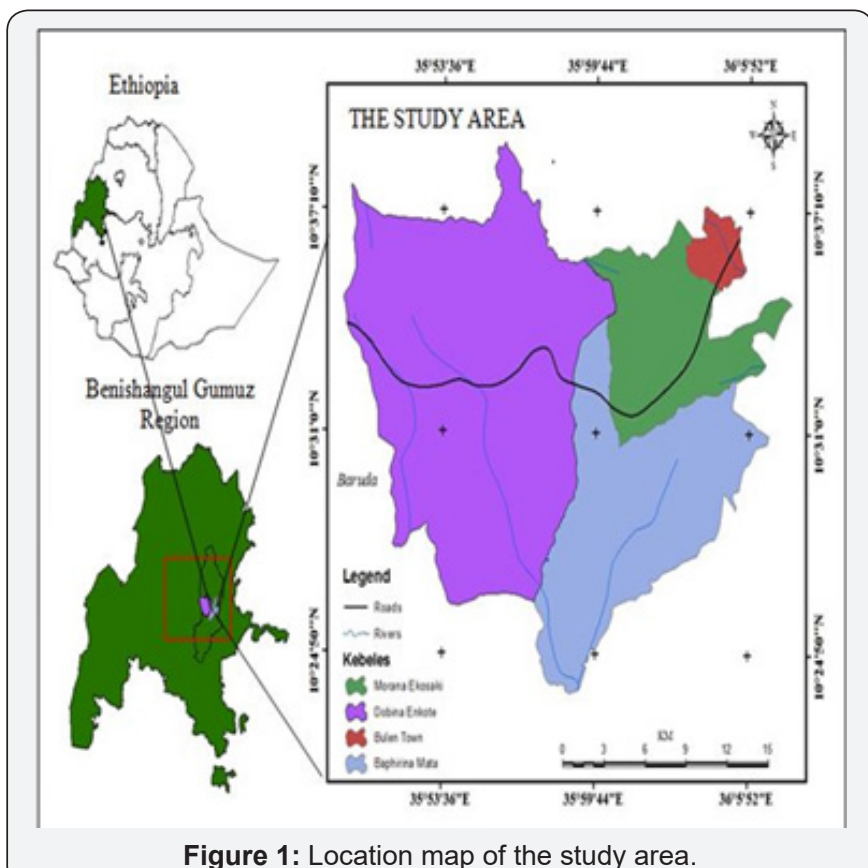

Figure 1: Location map of the study area.

From the surveyed 138 households in Bulen district, it was demonstrated that, $(80 \%)$ were practicing homegarden to grow different types of plants to fulfill various needs of household members. The overall size of home gardens in the study area ranges from 0.031 to 0.75 ha. The size range observed in this study is also considerably larger than the size range reported for most Ethiopian gardens (0.004-0.05ha) [9]. The range of home gardens sizes in the three categories were 0.031 ha- 0.25 , 0.25-0.5ha and 0.5- 0.75ha in small, medium and large sized home gardens, respectively. $54 \%$ of the households had medium 
sized home gardens ranging between $0.25-0.5$ ha followed by $38 \%$ (small) and 8\% (large) ranked in first, second and third, respectively (Table 2). So, the result of this study is dissimilar with [10]. In their study $100 \%$ of the surveyed households in the area practicing homegarden agroforestry while in this study $80 \%$ were practicing homegarden agroforestry and the size of home gardens in their study area ranges from $250 \mathrm{~m}^{2}-2000 \mathrm{~m}^{2}$

\section{Structure of Home Garden Agroforestry System}

with an average of $665.42 \mathrm{~m}^{2}$ while in this study $310 \mathrm{~m}^{2}-7500 \mathrm{~m}^{2}$. The result was dissimilar with due to the following reason, in this study site $90 \%$ of households have their owen farm land on the field and have less attention on producing homegarden agroforestry. Most of the surveyed home gardens (70\%) in Bulen district had rectangular shape while the remaining were irregular and square shape (Figure 1).



Figure 2: Percentage of plant species recorded in the studied homegardens.

Horizontal stratification: In the studied homegarden agroforestry system crops like maize, beans, pumpkin, and cabbage were common. So, this finding is similar with [11] in Spatial and temporal variation in crop diversity in agroforestry homegardens of southern Ethiopia. most common Plant species recorded in the homrgarden agroforestry system of the area were Maize (20\%), Cucumis sativus L (9\%), Azadirachta indica (9\%), Cordia africana (9\%), Sesbania sesban (7\%), Croton macrastachyus (6.5\%) and Mangifera indica (5.8\%) were the most planted species (Figure 2). These plant species provide multiple functions to the household like, food, income source, fuelwood and building materials. maize had the highest percent (20\%) which followed by Cucumis sativus L (9\%), Azadirachta indica (9\%), Cordia africana $(9 \%)$ and Sesbania sesban (6.5\%).

Data Collection Methods: The data were collected using the following data-collection instruments. Household survey Out of the 3253 household heads of the five Kebeles, household for survey were selected based on the following formula; $\mathrm{N}=$ (Godden. B, 2004).

Where; $\mathrm{N}=$ sample size

$\mathrm{Z}=$ the $\mathrm{z}$-value the desired degree of confidence

$\mathrm{P}=$ an estimate of the population proportion $\mathrm{e}=$ absolute size of the error in estimating $\mathrm{p}$ that the research is willing to permit

\section{Sampling of Home Gardens}

Homegarden size, horizontal and vertical arrangement of homegarden units, and plant species in different units were recorded in each garden. Horizontal structure was classified following [12]. Dividing homegarden into four quadrats, which means the first quadrat start from the farmers home to $10 \mathrm{~m}$, the second quadrat from $10 \mathrm{~m}$ to $20 \mathrm{~m}$, the third quadrat from $20 \mathrm{~m}$ to $30 \mathrm{~m}$ and the fourth quadrat from $30 \mathrm{~m}$ to $40 \mathrm{~m}$ horizontally were employed using farmer's house as reference and the different species within quadrat was recorded. Moreover, the number of vertical strata and the plant species occupying each stratum were recorded following the classification given to tropical homegarden by (Fernandez and Nair, 1986; and [13]. Accordingly, four vertical strata, $(<1 \mathrm{~m}, 1-5 \mathrm{~m}, 5-10 \mathrm{~m}$, and $>10 \mathrm{~m})$ were used for this stratification. Height measurement was carried out using clinometers for trees and measuring tape for herbaceous crop and also caliper for measuring DBH (Diameter at Brest Height) of each species. The numbers of plants per species were measured by counting all perennial plants and annual crops, in sample quadrats in systematically selected $5 \mathrm{mx} 5 \mathrm{~m}\left(25 \mathrm{~m}^{2}\right)$ and 1 $\times 1 \mathrm{~m}\left(1 \mathrm{~m}^{2}\right)$ quadrats, respectively. 


\section{Data Analysis}

For this study both quantitative and qualitative data analysis technique were used. Descriptive statistics methods such as densities, frequencies, abundance, dominance, relative frequencies, relative abundance, relative dominance, importance value index, Shannon and Wiener index for species diversity and Sorensen"s Index of similarity were used to analyze the data collected in sample quadrats of $1 \times 1 \mathrm{~m}\left(1 \mathrm{~m}^{2}\right)$ and $5 \mathrm{~m} \times 5 \mathrm{~m}$ $\left(25 \mathrm{~m}^{2}\right)$ in 110 home Gardens.

Structural Analysis: Species structure (frequency, density, abundance, basal area, and importance value index (IVI) of plant species in the homegarden were analyzed. Importance value index (IVI) was calculated by summing up relative frequency $(R F)$, relative density (RD) and relative dominance (RDO) values. The total number of species (species richness) were calculated by summing up the number of all the species encountered in home gardens. The importance value index (IVI) indicates the importance of individual tree/shrub species in the land use systems. It is a composite index based on the relative measures of species frequency, abundance and dominance [14]. This index was used to determine the overall importance of each species in the community structure. To calculate IVI of each species in the study area first the basal area and dominance of each species were calculated as:

$$
\mathrm{BA}=\pi \mathrm{r}^{2} \text { or } \mathrm{BA}=\pi \mathrm{d}^{2} / 4
$$

Dominant - most conspicuous and abundant species in the studied area and calculated as:

Dominance $=($ Total basal areaof the species $) /($ Totalsampled area)

Where: $\mathrm{BA}=$ basal area, $\pi=3.14, \mathrm{~d}=$ diameter at breast height of tree/shrubs, $r=d / 2$.

Relative dominance: Dominance of a species is determined by the value of the basal cover. Relative dominance is the coverage value of a species with respect to the sum of coverage of the rest of the species in the area.

Relative dominance $=($ Total basal area of species $) /($ Total basal area of all species) x100

\section{Density.}

Density is an expression of the numerical strength of a species where the total number of individuals of each species in all the quadrats is divided by the total number of quadrats studied. Density is calculated by the equation:

Density = (Total no.of individuals of species in all quadrats $) /$ (Total no.of quadrats studied)

Relative density: Relative density is the study of numerical strength of a species in relation to the total number of individuals of all the species and can be calculated as:

Relative density $=$ (Number of individual of species $) /$
(Number of individual of all species) x100

Frequency (\%).

Frequency describes the distribution of a species throughout the stands. It is determined by calculating the percentage of plots / quadrants in a sample area on which a given species occurs (Martin, 1995). It was studied by sampling the study area at several places at random and recorded the name of the species that occurred in each sampling units. It is calculated by the equation:

Frequency $(\%)=($ Number of quadrats in which the species occured)/(Total number of quadrats studied) $\times 100$

Relative frequency: Relative frequency is the number of occurrences of a species, as a percentage of the total

occurrences of all species (Martin, 1995).

Relative frequency $(\mathrm{RF})=\mathrm{x} 100$

Abundance: It is the study of the number of individuals of different species in the community per unit area. By quadrats method, samplings are made at random at several places and the number of individuals of each species was summed up for all the quadrats divided by the total number of quadrats in which the species occurred. It is represented by the equation:

Abundance $=($ Total number of individuals ofa species in all quadrats)/(Total number of quadrats in which the species occurred)

Relative abundance: The quantitative pattern of rarity and commonness among species in a sample.

Relative abundance (RA)

Finally, IVI=RA + RD + RF; where, IVI-Important value indices, RA-relative abundance, RD-relative dominance and RF-relative frequency.

Similarity and dissimilarity indices: Variation in species composition among the different homegardens were determined using Beta diversity, calculated as $\beta=1-\mathrm{Cj}$, where $\mathrm{Cj}$ is Jaccard's similarity index (Magurran, 1988), $\mathrm{C} \mathrm{j}=\mathrm{j} /(\mathrm{a}+\mathrm{b}-\mathrm{j})$, where $\mathrm{j}=$ the number of species shared by any two sites a and $b, a=$ the number of species in site $a$, and $b=$ the number of species in site b.

Species richness, diversity and dominance indices: The species richness of the vascular plants was calculated by using the method 'Margalef's index of richness' (Dmg) (Magurran, 1988).

$$
\text { Dmg }=(\mathrm{S}-1) / \mathrm{In} N
$$

Where, $\mathrm{S}=$ Total number of species. $\mathrm{N}=$ Total number of individuals.

Shannon and Wiener Diversity Index: The ShannonWeiner Index is the most commonly used diversity indicator in 
plant communities, and it takes a value of zero when there is only one species in a community, and a maximum value when all species are present in equal abundance (Shannon and Wiener, 1949). To determine the diversity of plant species we calculated species richness, Shannon index and Evenness measure (E). Shannon diversity index is calculated as $\left(\mathrm{H}^{\prime}\right)=$ (Magurran,1988), where pi is the proportion of crop area composed of species i. The measure of evenness (E) which is the ratio of observed diversity to maximum diversity is calculated as $\mathrm{E}=\mathrm{H}^{\prime} / \mathrm{Hmax}$, $=\mathrm{H}^{\prime} /$ In (Magurran, 1988), where $\mathrm{H}^{\prime}$ is a diversity index, Hmax and In the highest and lowest values of this index for the given number of species and the sample size.

\section{Results and Discussion}

\section{General features of homegarden agroforestry}

The spatial arrangement of homegarden agroforestry is variable in the study area. About $83 \%$ of homegarden agroforestry is located in the backyard while a few were located on the side of the homestead. Most of the studied homegarden agroforestry $(78 \%$; $=110)$ were surrounded by live fence of the species Justicia schimperiana, Azadirachta indica, Erythrina abyssinica, Cordia africana, Croton macrastachyus, and Acacia nilotica and the rest $22 \%$ are semi-fenced and open.

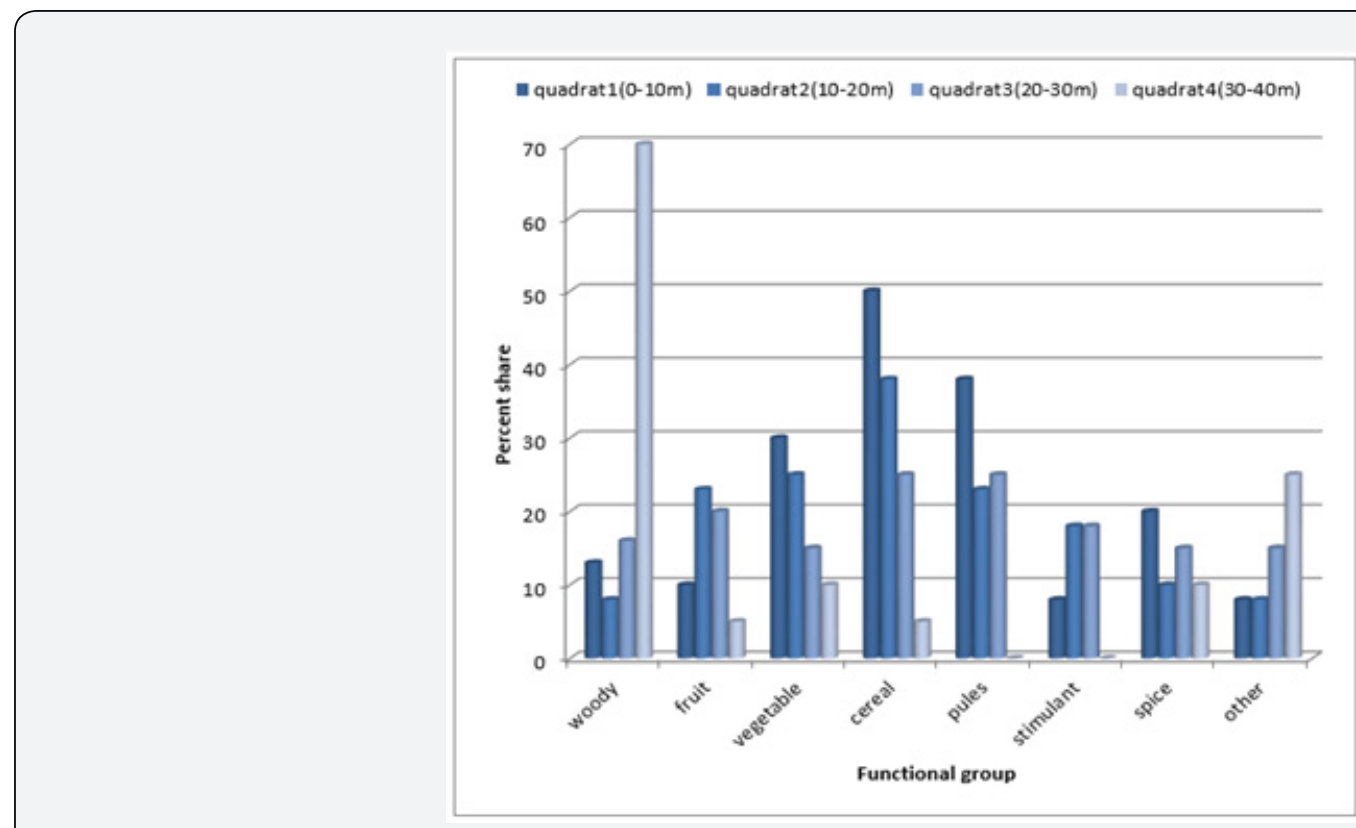

Figure 3: Functional group of plant species across horizontal stratification.

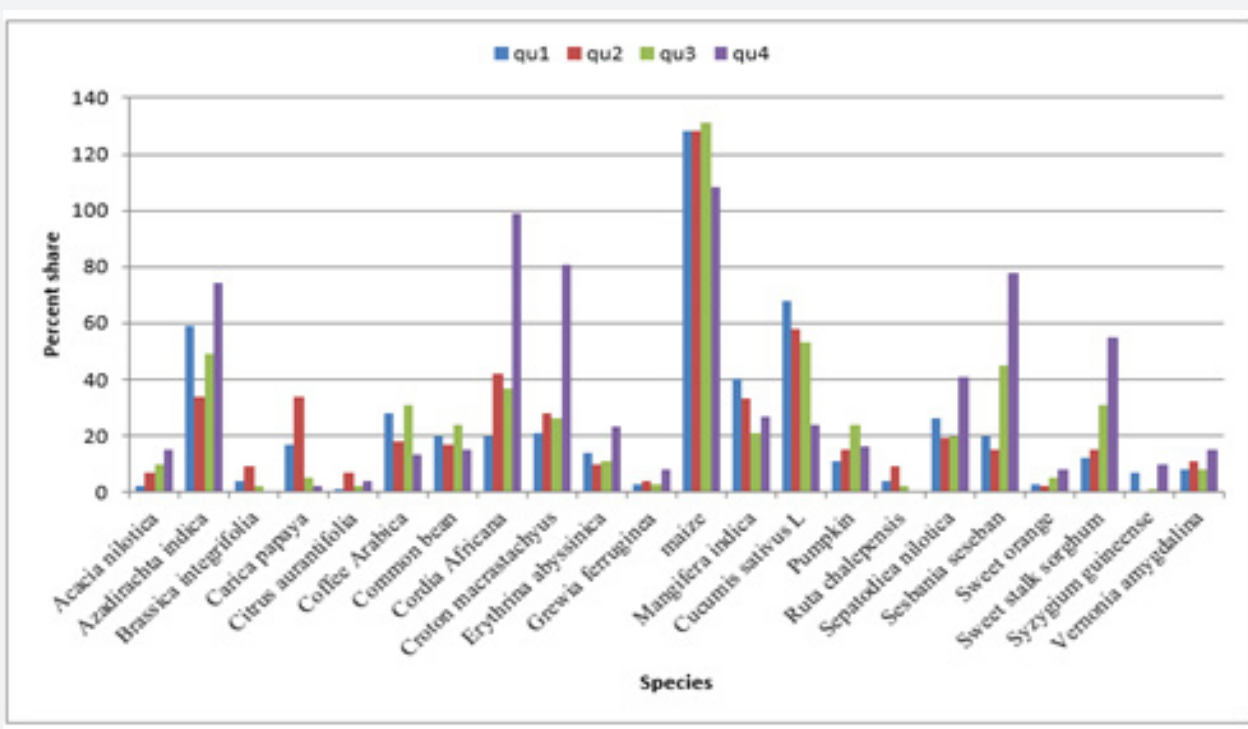

Figure 4: Horizontal distribution of individual species in each quadrat.

The species composition varies highly with increase in the size of homegardens. For all sampled homegarden agroforestry the horizontal structure of species was determined by the owner of the household. Generally, the studied homegardens showed 
a distinct horizontal structure arrangements zone between perennial plants and annual crops. Further away mainly in the middle of the gardens, vegetables, annual crops and fruits were typical features of most of the gardens (Figure 3). The result is similar with [15] that reported the same result in plant species diversity of homegarden agroforestry in Jabithenan district north-western Ethiopia. Horizontal structure of the species declines as one goes from the first quadrat to the fourth quadrat or out of the fields. Similar results were reported by [16] in coffee-enset-based Sidama homegardens and Talemos, (2007) enset-based homegardens in Welayita.

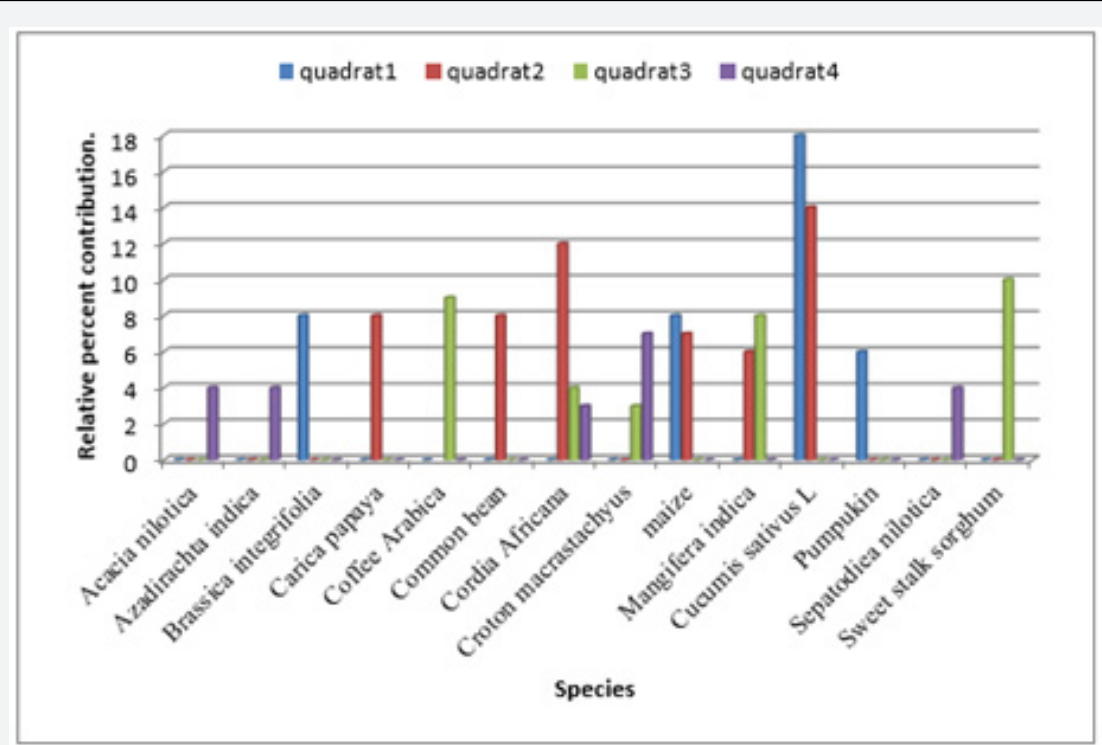

Figure 5: Proportion of top five species per quadrat across horizontal stratification.

The species recorded in each quadrat was grouped into functional groups and their extent of horizontal distribution was quantified as percent share relative to each other in the 110 studied homegarden agroforestry. Woody species are highly concentrated in the fourth quadrat, fruits and vegetable are more frequently recorded in the second quadrat, cereal crops, pulse and spices are highly recorded in quadrate one. On the boarder of the gardens tree species like Justicia schimperiana, Azadirachta indica, Erythrina abyssinica, Cordia Africana, Croton macrastachyus, Acacia nilotica, Sepatodiea nilotica, and Vernonia amygdalin which serve for live fence, fuel, pole and construction material were the dominant and each individual species was also distributed haphazardly in each quadrant (Figure 4). Proportion of top five species per quadrat across horizontal structure of homegarden agroforestry system was presented in Figure 5. It was indicated that species in the first quadrat have high contribution than the other three quadrats. The result indicated that as one cross from first to fourth quadrat the relative percent contribution of the species decreases.

The species richness also showed declining trend from quadrat 1 to quadrat 4 (Figure 6). Species richness varies from quadrat to quadrat indicating decrease with increasing distance from quadrat one to quadrat four or out of the field. Quadrat 1 had the highest species richness than the other quadrats. reported similar result in study of plant species richness and structure of homegarden agroforstry in Jabithenan District, North-Western Ethiopia. In the other side horizontal structure of different functional groups in each individual kebele was shown in (Figure 7). cereal crops and pulse were highly recorded in the first quadrat, vegetable and fruit were in the second and third quadrat respectively while woody species have highly recorded in the fourth quadrat. This finding was disparity with the report of Zebene et al., (2015) in study of plant species richness and structure of homegarden agroforestry in Jabithenan District, North- Western Ethiopia. In the current study area farmers grow cereal crops in the homegarden using spatial arrangement for the different components. woody species are planted in the fourth quadrat to use trees as windbreak and avoid shading effect on food crops. the result revealed that a total of seven functional groups of plant species were recorded in the homegardens of area. Out of the total of 22 plant species, most species were woody plants $(28 \%)$ followed by cereal crops $(25 \%)$, fruits $(15 \%)$ and vegetables $(12 \%)$. Other functional groups included pulses crops (7\%), stimulant crops $(5 \%)$, spices crops $(4.5 \%)$ and the other group (3.5\%).

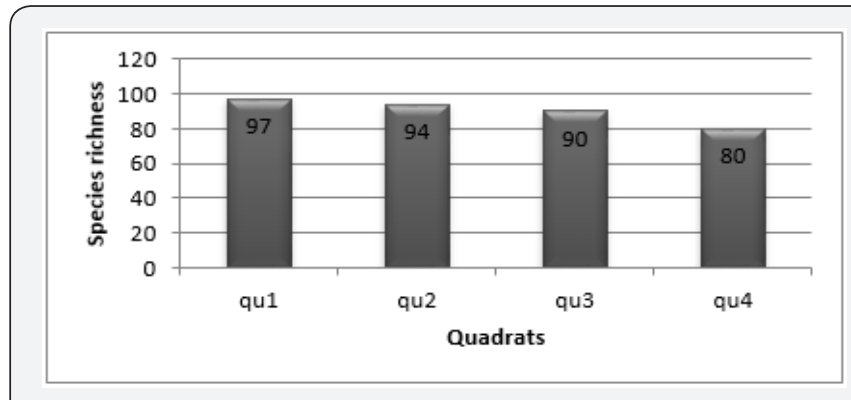

Figure 6: Proportion of top five species per quadrat across horizontal stratification. 

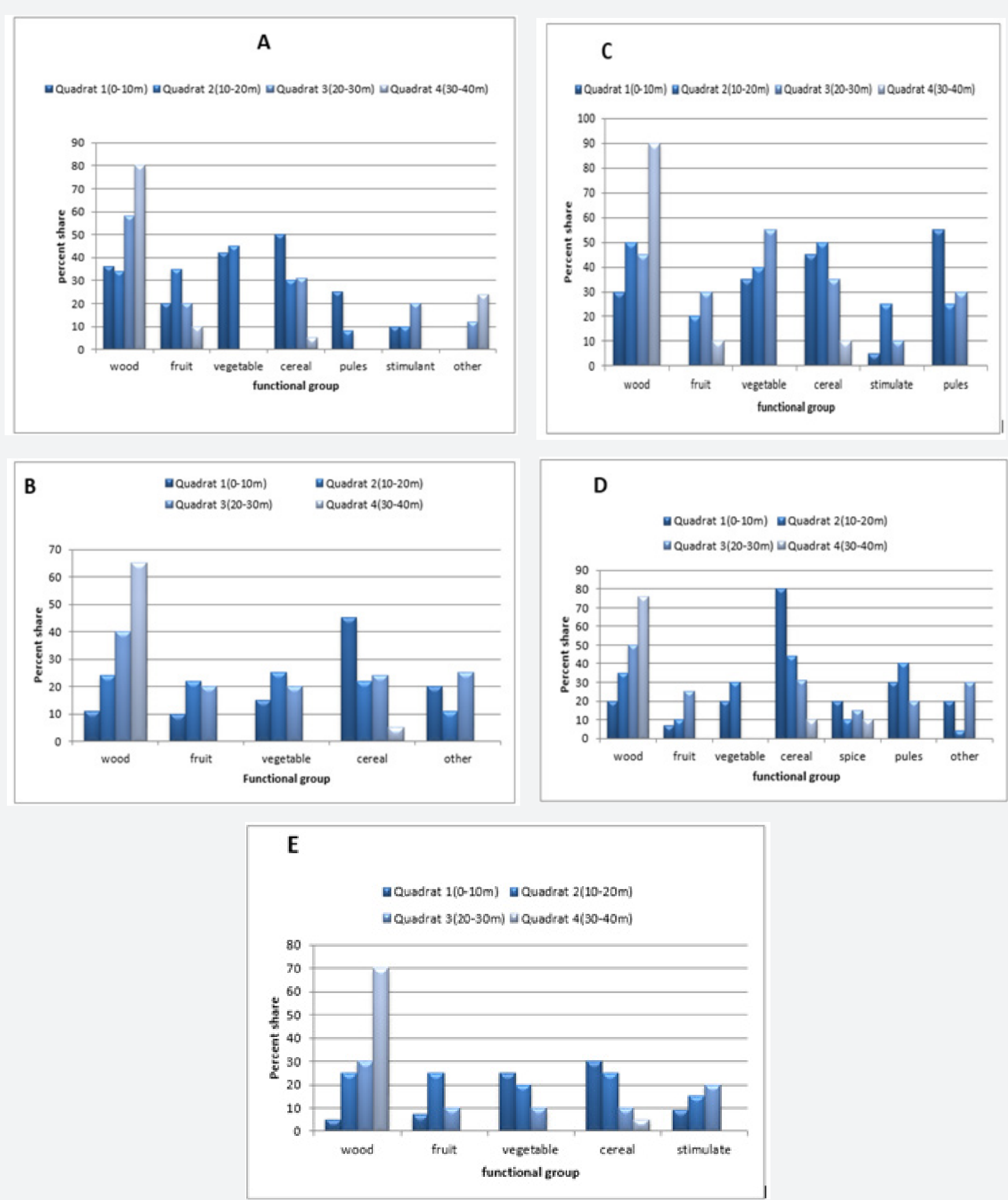

Figure 7: Horizontal stratification of different functional groups in Baruda(A), Dobi(B), Mata(C), Mora(D) and Bulen 01(E) kebeles.

\section{Vertical Stratification of Plant species}

The relative percent contribution of each species, species richness and species distribution in each height strata, are shown Figure 8,9 and 10 respectively. In Figure 8 the bottom layer were highly dominated by vegetables, shrub layers were dominated by cereal crops and fruits, while the main canopy and upper storey layer were dominated by woody plants. 


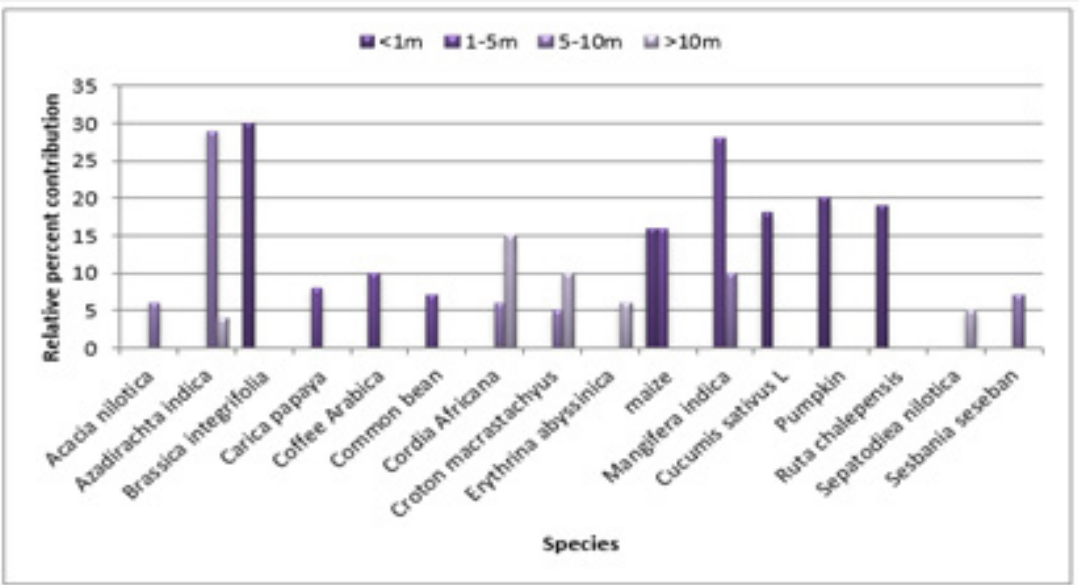

Figure 8: The top five relativ percent contribution of homegarden plant species to different height class

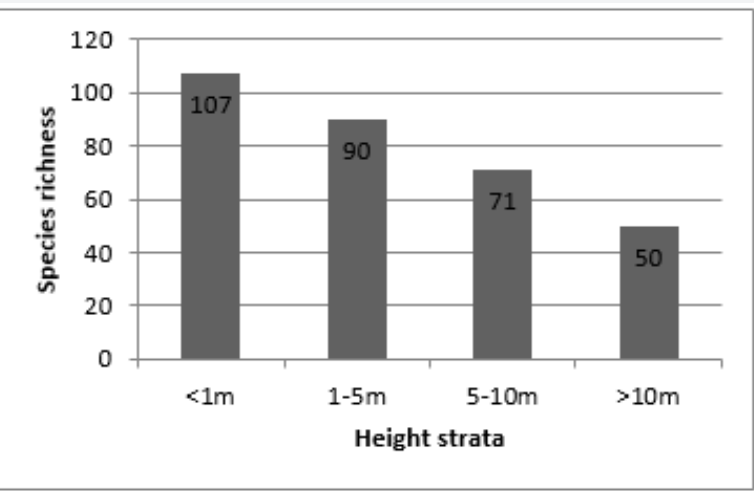

Figure 9: Species richness across homegarden agroforestry in each height strata.

the species richness decreased with increasing height from the bottom layer to upper storey of height strata (Figure 9). This result was in line with the report of Zebene et al., (2015). the bottom layer were highly contributed by vegetables, shrub layer were dominated by fruit, stimulant and cereal crops, canopy layer were dominated by some fruit and woody species while the upper storey were highly contributed by wood species.

Vertical structure of homegarden agroforestry (Figure 10) in an individual household reflects the species degree of specialization and complexity. The studied homegarden is an assemblage of multipurpose trees, fruits, vegetables, cereal crops, stimulants and herb with some climbers in the boarder. Accordingly, vertical stratification in the study homegarden is categorized in to four major strata; upper storey $(>10 \mathrm{~m})$, main canopy (5-10m), shrub layer (1-5m) and bottom layer $<1 \mathrm{~m}$. The upper storey is dominated by broadleaved trees (Cordia africana, Croton macrostachyus, Azadirachta indica, Erythrina abyssinica, Acacia nilotica, and Sepatodiea nilotica). The main canopy containing fruit trees like Carica papaya, Mangifera indica, Citrus sinensis(L), Citrus aurantifolia; Shrub layer dominated by stimulants (Coffea arabica), cereal crops(maize) and bottom layer by vegetable (Cucumis sativus L, Brassica integrifolia,Cucrbita pepo L) spice species (Ruta chalepensis) (Figure 10). This finding supports the report of Zebene et al., (2015).

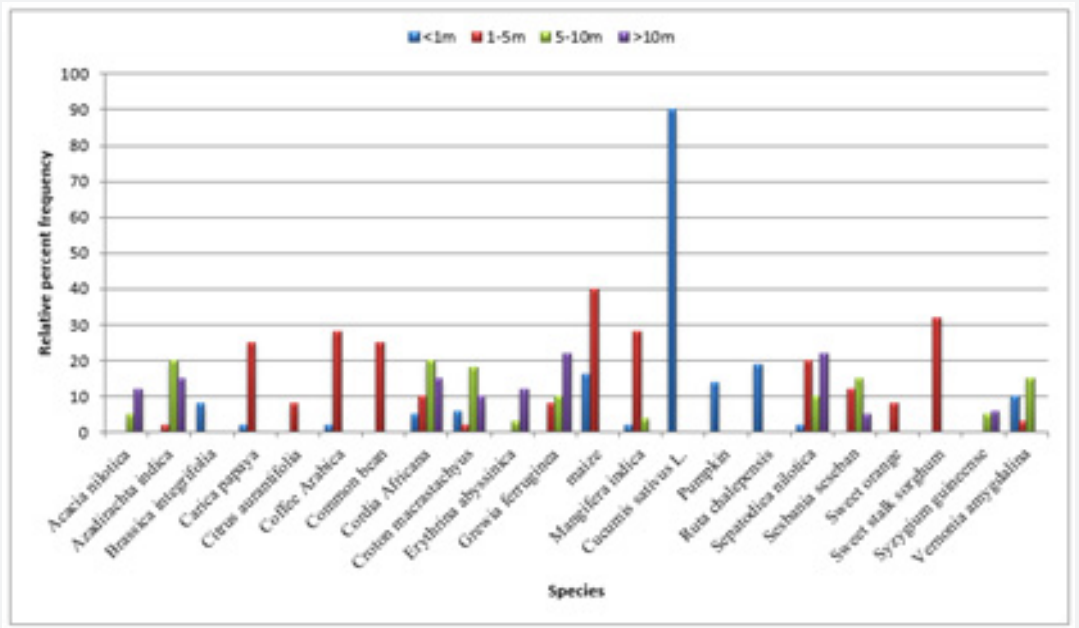

Figure 10: Vertical distribution of individual species in each height strata. 


\section{Composition and Diversity of Plant Species}

A total of 22 plant species were identified from the study area. These plant species were classified into 15 families. The families which recorded in the study district were, Fabaceae, Rutaceae, Poaceae, Cucurbitaceae, Maliaceae, Brassicaceae, Caricaceae, Rubiaceae, Boraginaceae, Euphotbiaceae, Tiliaceae, Anacardiaceae, Bignoniaceae, Myrtaceae and Asterceae. Similarly, Melese and Daniel (2015) reported that Fabaceae, Poaceae and Cucurbitaceae families were recorded in Dilla Zuriya Woreda, Gedeo Zone, SNNPRS, Ethiopia. The commonly represented families were Fabaceae which contains 4 species, followed by Rutaceae, Poaceae and Cucurbitaceae in the second and third rank, with 3,2 and 2 species and the other 11 families were found on the 5th rank which contains one species in each family.

The homegarden in Bulen district is composed of $25 \%$ cereal crop (maize), 15\% fruit trees like (Carica papaya, Mangifera indica, Citrus sinensis(L), Citrus aurantifolia), $7 \%$ pulse (common bean), 5\% stimulants (Coffea arabica) , (12\%) vegetable (Cucumis sativus L, Brassica integrifolia, Cucrbita pepo L) 4.5\% spice species (Ruta chalepensis), (28\%) woody plants such as Acacia nilotica, Azadirachta indica, Cordia africana, Croton macrostachyus, Sepatodiea nilotica ,Erythrina abyssinica, and Grewia ferruginea, and (3.5\%) by other species (Figure 7).
From the total number of species recorded in the study area, Cucumis sativus L (98\%), was the most frequent species, followed by Zea mays L (88.54\%) and Grewia ferruginea (83.3\%) respectively. The value of Shannon-Wiener diversity index of sites ranged from 2.21 to 2.44 (Table 3 ). The result was in line with the finding of Zebene et al., (2015) which ranges from 2.262.43 for woody species and 2.28-2.55 for herbaceous species in homegarden agroforstry at four villages of Jabithenan District, Ethiopia. The shannon diversity index showed a higher diversity of plant species in Baphirina Mata homegarden $\left(\mathrm{H}^{\prime}=2.44\right)$ as compared to the homegardens of Baruda and Morana Ekosaki $\left(H^{\prime}=2.36\right)$, Bulen $01\left(H^{\prime}=2.23\right)$ and Dobina Enkonti $\left(H^{\prime}=2.21\right)$ (Table 3). Dominance index showed that only a few species dominated the homegardens in Dobina Enkonti $(\lambda=0.226)$ as compared to Baruda $(\lambda=0.095)$, Baphirina Mata $(\lambda=0.095)$, Bulen 01 (0.096) and Morana Ekosaki $(\lambda=0.137)$ homegardens (Table3). The finding was in disagreement with the Zebene et al. (2015) that report dominance index of woody and herbaceous species in homegarden agroforestry in Jebithenan district North-Western Ethiopia, ranged from 0.79-0.83 and 0.85-0.90 respectively. The evenness index showed that in Dobina Enkonti and Baphirina Mata homegardens most of the species are equally abundant $(\mathrm{E}=0.92)$ than Baruda and Bulen 01 ( $\mathrm{E}=0.89)$, and Morana Ekosaki (E=0.85) homegardens(Table3). The diversity index was less in the Dobina Enkonti homegardens suggesting that only few plants species were more abundant.

Table 3: Species evenness, Simpson's index of dominance, Species richness and Species diversity.

\begin{tabular}{|c|c|c|c|c|}
\hline Site & Evenness (E) & $\begin{array}{c}\text { Simpson's index of dominance } \Sigma \\
\left(\mathbf{p}_{\mathbf{i}} \mathbf{2}\right.\end{array}$ & Species richness D= & Species diversity H=- \\
\hline Baruda & 0.89 & 0.095 & 0.58 & 2.36 \\
\hline Dobi & 0.92 & 0.226 & 0.57 & 2.21 \\
\hline Mata & 0.92 & 0.095 & 0.70 & 2.44 \\
\hline Mora & 0.85 & 0.137 & 0.73 & 2.36 \\
\hline Bulen01 & 0.89 & 0.096 & 0.63 & 2.23 \\
\hline
\end{tabular}

Table 4: Level of Similarity index among sites in respect to composition of plant species.

\begin{tabular}{|c|c|c|c|c|c|}
\hline Site & Baruda & Dobina Enkonti & Baphirina Mata & Morana Ekosaki & Bulen 01 \\
\hline Bullen 01 & 0.5 & 0.53 & 0.62 & 0.47 & 1 \\
\hline Morana Ekosaki & 0.55 & 0.5 & 0.42 & 1 & \\
\hline Baphirina Mata & 0.44 & 0.31 & 1 & & \\
\hline Dobina Enkonti & 0.64 & 1 & & \\
\hline Baruda & 1 & & & \\
\hline
\end{tabular}

Similarity index of the study area ranged from $0.31-0.64$, $60 \%$ of the similarity index is greater than 0.5 and $40 \%$, is less than 0.5 indicating the existence of high similarities/ low species diversity among the recognized sites (Table 4). There are similarities in plant species composition among the kebeles. The closely located Dobina Enkonti and Bruda kebeles from Bulen district had the more similarity index, which means that they shared $64 \%$ of the plant species. On the other hand, Baphirina Mata and Dobina Enkonti had the least similarity index which means that they share $31 \%$ of the plant species (Table 4 ).

Table 5: dominance, frequency, abundance, relative dominance, relative frequency, relative abundance and important value index.

\begin{tabular}{|c|c|c|c|c|c|c|c|c|c|c|}
\hline \multirow{2}{*}{ Species name } & \multicolumn{2}{|c|}{ Dominance } & \multicolumn{2}{|c|}{ Frequency } & \multirow{2}{*}{ Abundance } & \multirow{2}{*}{$\begin{array}{l}\text { Relative domi- } \\
\text { nance }\end{array}$} & \multirow{2}{*}{$\begin{array}{l}\text { Relative } \\
\text { frequency }\end{array}$} & \multirow{2}{*}{$\begin{array}{c}\text { Relative } \\
\text { abundance }\end{array}$} & \multicolumn{2}{|c|}{ IVI } \\
\hline & & rank & & rank & & & & & & rank \\
\hline Acacia nilotica & 0.036 & $16^{\text {th }}$ & 50 & $17^{\mathrm{st}}$ & 1.7 & 16.22 & 20.78 & 22 & 59 & $15^{\text {th }}$ \\
\hline
\end{tabular}


International Journal of Environmental Sciences \& Natural Resources

\begin{tabular}{|c|c|c|c|c|c|c|c|c|c|c|}
\hline Azadirachta indica & 0.049 & $13^{\text {th }}$ & 72.2 & $7^{\text {st }}$ & 1.78 & 24 & 28.76 & 20.89 & 73.65 & $10^{\text {th }}$ \\
\hline Brassica integrifolia & 0.029 & $21^{\text {th }}$ & 55 & $15^{\text {st }}$ & 3.37 & 17.84 & 18.21 & 25.94 & 62 & $14^{\text {th }}$ \\
\hline Carica papaya & 0.045 & $15^{\text {th }}$ & 45 & $20^{\text {st }}$ & 3.93 & 23.41 & 28.82 & 30.48 & 82.71 & $6^{\text {th }}$ \\
\hline Citrus aurantifolia & 0.033 & $19^{\text {th }}$ & 50 & $17^{\text {st }}$ & 1.8 & 14.65 & 17.82 & 20.52 & 53 & $17^{\text {th }}$ \\
\hline Coffee arabica & 0.074 & $6^{\text {th }}$ & 77.5 & $4^{\mathrm{st}}$ & 3.18 & 30.88 & 28.89 & 34.54 & 94.4 & $5^{\text {th }}$ \\
\hline Phaseous vulgaris $L$ & 0.035 & $17^{\text {th }}$ & 57.77 & $12^{\text {st }}$ & 2.0 & 12.58 & 18.25 & 15.13 & 45.96 & $21^{\text {th }}$ \\
\hline Cordia africana & 0.64 & $1^{\text {st }}$ & 59.55 & $11^{\mathrm{st}}$ & 2.5 & 24 & 24.86 & 22.45 & 71.31 & $11^{\text {th }}$ \\
\hline $\begin{array}{c}\text { Croton macrastachy- } \\
\text { us }\end{array}$ & 0.068 & $8^{\text {th }}$ & 73 & $6^{\text {st }}$ & 2.17 & 24.22 & 27.54 & 23 & 74.76 & $7^{\text {th }}$ \\
\hline Erythrina abyssinica & 0.072 & $7^{\text {th }}$ & 54.2 & $16^{\text {st }}$ & 2.6 & 30.05 & 23.6 & 20.1 & 73.75 & $8^{\text {th }}$ \\
\hline Grewia ferruginea & 0.062 & $10^{\text {th }}$ & 83.3 & $3^{\text {st }}$ & 1.78 & 13.6 & 25 & 12.4 & 51 & $18^{\text {th }}$ \\
\hline Zea mays $L$ & 0.13 & $3^{\text {rd }}$ & 88.54 & $2^{\mathrm{st}}$ & 5.15 & 52.55 & 32.7 & 41.27 & 126.52 & $2^{\text {nd }}$ \\
\hline Mangifera indica & 0.053 & $12^{\text {th }}$ & 69.82 & $8^{\mathrm{st}}$ & 1.82 & 18.34 & 25.63 & 18.98 & 62.95 & $13^{\text {th }}$ \\
\hline Cucumis sativus $L$ & 0.156 & $2^{\text {nd }}$ & 98 & $1^{\text {st }}$ & 10 & 58.6 & 38.23 & 48.05 & 144.88 & $1^{\text {st }}$ \\
\hline Cucrbita pepoL & 0.034 & $18^{\text {th }}$ & 57.1 & $13^{\text {st }}$ & 2.01 & 15.77 & 18.12 & 14.35 & 48.24 & $20^{\text {th }}$ \\
\hline Ruta chalepensis & 0.021 & $22^{\text {th }}$ & 50 & $17^{\mathrm{st}}$ & 2.33 & 12 & 14.13 & 16.5 & 42.63 & $22^{\text {th }}$ \\
\hline Sepatodiea nilotica & 0.058 & $11^{\text {th }}$ & 61 & $10^{\text {st }}$ & 2.02 & 23.79 & 26.42 & 23.52 & 73.73 & $9^{\text {th }}$ \\
\hline Sesbania seseban & 0.123 & $4^{\text {th }}$ & 56.3 & $14^{\mathrm{st}}$ & 9.9 & 44.55 & 21.31 & 51.35 & 117.21 & $3^{\text {rd }}$ \\
\hline Citrus sinensis $(L)$, & 0.033 & $19^{\text {th }}$ & 75 & $5^{\text {st }}$ & 2.12 & 21.77 & 26.65 & 19.4 & 67.82 & $12^{\text {th }}$ \\
\hline Sorghum dochna & 0.08 & $5^{\text {th }}$ & 41.66 & $22^{\mathrm{st}}$ & 5.18 & 38.85 & 24.14 & 39.82 & 102.81 & $4^{\text {th }}$ \\
\hline Syzgium guineense & 0.047 & $14^{\text {th }}$ & 43.75 & $21^{\text {st }}$ & 2.37 & 14.25 & 14.22 & 21.05 & 49.52 & $19^{\text {th }}$ \\
\hline Vernonia amygdalina & 0.068 & $8^{\text {th }}$ & 67.85 & $9^{\text {st }}$ & 2.43 & 16.62 & 23.28 & 18.45 & 58.35 & $16^{\text {th }}$ \\
\hline
\end{tabular}

Species like Zea mays L, Cordia africana, Sorghum dochna, Azadirachta indica, and Sepatodiea nilotica were more abundant than others in the Dobina Enkonti homegardens but many other species were equally abundant in the Baphirina Mata, Baruda, Morana Ekosaki and Bulen 01 homegardens, species like Mangifora indica, Croton macrastachyus, Acacia nilotica, Coffee arabica, Carica papaya, Citrus aurantifolia, Grewia ferruginea, and Erythrina abyssinica (Table 5).

\section{Conculusion}

Agroforestry homegardens are common in most tropical countries and they play a vital role in supporting households in many diverse ways, including provision of food, fuel wood, building materials, and fodder for livestock, and income. The aim of this study was to investigate the structure, composition and diversity of plant species growing in homegarden agroforestry system and to assess the economic contributions of homegardens to households in Bulen district, North-west Ethiopia. The study was conducted in five kebeles of the Woreda, namely (Baruda, Bulen 01, Dobina Enkonti, Baphirina Mata, and Morana Ekosaki) which were randomly selected. Systematic random sampling procedure was employed to select householdrs from each kebeles. All woody species and herbaceous species were counted and recorded in $5 \mathrm{~m} \times 5 \mathrm{~m}\left(25 \mathrm{~m}^{2}\right)$ and $1 \mathrm{mx} 1 \mathrm{~m}\left(1 \mathrm{~m}^{2}\right)$ quadrats, respectively. This study revealed that the homegardens of the study area ranges from 0.031 ha $-0.75 \mathrm{ha}$. In a survey of plant species diversity in 110 homegardens a total of 22 plant species within 7 functional groups were recorded; there were on average 6 plant species per farm. The highest Shannon diversity index in the study area is $\left(\mathrm{H}^{\prime}=2.44\right)$ and the lowest is $\left(\mathrm{H}^{\prime}=2.21\right)$.

Generally, the studied homegardens showed a distinct horizontal structure arrangements zone between perennial plants and annual crops and horizontal structure of the species declines as one goes from the first quadrat to the fourth quadrat or out fields. Accordingly, vertical stratification in the study homegarden is categorized in to four major strata; The upper storey is dominated by broadleaved trees, the main canopy containing fruit trees, Shrub layer dominated by stimulants and bottom layer by vegetables. In the study area homegardens can also contributes economical income in different direction. So, household get the highest income from crop production $47 \%$ which is followed by fuel wood, building materials and fruit production, $22 \%$ and $17 \%$ respectively. Vegetable and livestock production were the fourth- and fifth-income source to the households respectively. The homegarden in Bulen district is composed of $25 \%$ cereal crop (maize), 15\% fruit trees like (Carica papaya, Mangifera indica, Citrus sinensis(L), Citrus aurantifolia), $7 \%$ pulse (common bean), 5\% stimulants (Coffea arabica) , (12\%) vegetable (Cucumis sativus L, Brassica integrifolia, Cucrbita pepo L) $4.5 \%$ spice species (Ruta chalepensis), (28\%) woody plants such as Acacia nilotica, Azadirachta indica, Cordia africana, Croton macrostachyus, Sepatodiea nilotica ,Erythrina abyssinica, and Grewia ferruginea, and (3.5\%) by other species. 


\section{References}

1. Kumar BM, Nair PKR (2006) Tropical home gardens. A time-tested example of sustainable agroforestry, Advances in Agroforestry, 3 Springer, Dordrecht.

2. Albuquerque UP, Andrade LHC, Caballero J (2005) Structure and floristic of homegardens in north-eastern Brazil. Arid environment 62(3):491-506.

3. Fernandes ECM, PKR Nair (1986) An evaluation of the structure and function of tropical homegardens. Agricultural Systems 21(4): 179310.

4. Kumar BM, Nair PKR (2004) The enigma of tropical homegardens. Agroforest Systems 61(1-3): 135-152.

5. Magurran AE (1988) Introduction measurement of (biological) diversity Sample chapter one in Ecological diversity and its measurement. Princeton University Press, Princeton 83-119.

6. Huston MA (1994) Biological diversity: the coexistence of species on changing landscapes. Cambridge University Press, USA.

7. LamontSR,EshabughWH(1999)Speciescomposition diversityanduseof homegardens among three Amazonian village; Economic Botany 54(3): 312-316.

8. Galluzzi G, Eyzaguirre P, Negri V (2010) Homegardens neglected hotspots of agrobiodiversity and cultural diversity. Biodiversity and Conservation. 19(13): 3635-3654.

9. Zemede A, Ayele N (1995) Homegardens in Ethiopia characteristics and plant diversity. Ethiopian Journal of Science 18(2):235-266.

10. Melese Mengitu, Daniel Fitamo (2015) Plant Species Diversity and Composition of the Homegardens in Dilla Zuriya Woreda, Gedeo Zone, SNNPRS, Ethiopia. Plant 3(6): 80-86.
11. Tesfaye Abebe, KF Wiersum, F Bonger (2009) Spatial and temporal variation in crop diversity in agroforestry homegardens of southern Ethiopia 78(3): 309-322.

12. Millate M, Johna B, Zewege $T$ (1996) Structure and floristic of Bangladesh homrgardens. Agroforestry systems 33(3): 263-280

13. Fentahun Mengistu (2008) Fruit tree species in the wild and in homegarden agroforestry: Species composition, diversity and utilization in western Amhara region, Ethiopia. PhD Thesis Vienna University, Vienna.

14. Kent M, Coker P (1992) Vegetation Description and Analysis. A practical approach. Belhaven press, London, pp. 263.

15.Zebene Asfaw, Ewuketu Linger, Solomon Zewudie (2015) Plant Species Richness and Structure of Homegarden Agroforestry in Jabithenan District, North-Western Ethiopia. International Journal of Environmental Sciences 4(2): 52-58.

16. Tesfaye Abebe (2005) Diversity in homegarden agroforestry systems of southern Ethiopia. Wageningen University, the Netherlands, Tropical Resource Management Paper 59: 143.

17. Fernandes ECM, Oktingati A, Maghembe J (1984) The Chagga homegardens: A multi storeyed agroforestry cropping systems on Mt. Kilimanjaro, Northern Tanzania. Journal of Agroforestry Systems 2: 73-86.

18. Pandey C, Kanak L, Venkatesh A, Mehdi R (2006) Diversity and species structure of homegardens in south Andaman, India. Tropical Ecology 47(2): 251-258.

19. Shannon CE, Wiener W (1949) The mathematical theory of Communication. Unversity of Illions Press. Urbana III.

\section{Your next submission with Juniper Publishers} will reach you the below assets

- Quality Editorial service

- Swift Peer Review

- Reprints availability

- E-prints Service

- Manuscript Podcast for convenient understanding

- Global attainment for your research

- Manuscript accessibility in different formats ( Pdf, E-pub, Full Text, Audio)

- Unceasing customer service

Track the below URL for one-step submission https://juniperpublishers.com/online-submission.php 